Article

\title{
Synergistic Combinations of Curcumin, Sulforaphane, and Dihydrocaffeic Acid against Human Colon Cancer Cells
}

\author{
Jesús Santana-Gálvez ${ }^{1}{ }^{\circledR}$, Javier Villela-Castrejón ${ }^{1}{ }^{\circledR}$, Sergio O. Serna-Saldívar ${ }^{1}$, \\ Luis Cisneros-Zevallos ${ }^{2}$ and Daniel A. Jacobo-Velázquez ${ }^{1, *(D)}$ \\ 1 Tecnologico de Monterrey, Escuela de Ingeniería y Ciencias, Ave. Eugenio Garza Sada 2501, \\ Monterrey, NL C.P. 64849, Mexico; jsantanag2000@gmail.com (J.S.-G.); jvillela.cas@tec.mx (J.V.-C.); \\ sserna@tec.mx (S.O.S.-S.) \\ 2 Department of Horticultural Sciences, Texas A\&M University, College Station, TX 77843-2133, USA; \\ lcisnero@tamu.edu \\ * Correspondence: djacobov@tec.mx; Tel.: +52-33-3669-3000
}

Received: 12 April 2020; Accepted: 26 April 2020; Published: 28 April 2020

\begin{abstract}
Nutraceutical combinations that act synergistically could be a powerful solution against colon cancer, which is the second deadliest malignancy worldwide. In this study, curcumin (C), sulforaphane (S), and dihydrocaffeic acid (D, a chlorogenic acid metabolite) were evaluated, individually and in different combinations, over the viability of HT-29 and Caco-2 colon cancer cells, and compared against healthy fetal human colon (FHC) cells. The cytotoxic concentrations to kill 50\%, $75 \%$, and $90 \%$ of the cells $\left(\mathrm{CC}_{50}, \mathrm{CC}_{75}\right.$, and $\left.\mathrm{CC}_{90}\right)$ were obtained, using the MTS assay. Synergistic, additive, and antagonistic effects were determined by using the combination index (CI) method. The 1:1 combination of $S$ and D exerted synergistic effects against HT-29 at $90 \%$ cytotoxicity level (doses 90:90 $\mu \mathrm{M})$, whereas $\mathrm{CD}(1: 4)$ was synergistic at all cytotoxicity levels (9:36-34:136 $\mu \mathrm{M})$ and $\mathrm{CD}(9: 2)$ at $90 \%(108: 24 \mu \mathrm{M})$ against Caco-2 cells. SD(1:1) was significantly more cytotoxic for cancer cells than healthy cells, while $\mathrm{CD}(1: 4)$ and $\mathrm{CD}(9: 2)$ were similarly or more cytotoxic for healthy cells. Therefore, the $\mathrm{SD}(1: 1)$ combination was chosen as the best. A model explaining $\mathrm{SD}(1: 1)$ synergy is proposed. $\mathrm{SD}(1: 1)$ can be used as a basis to develop advanced food products for the prevention/co-treatment of colon cancer.
\end{abstract}

Keywords: nutraceutical combinations; synergism; colon cancer; combination index; MTS assay

\section{Introduction}

Cancer, a chronic disease, is the second leading cause of death worldwide, accounting for millions of fatalities every year [1]. Nutraceuticals are promising compounds naturally found in foods that have preventive and therapeutic properties against chronic diseases. Hence, foods rich in nutraceuticals may be an alternative for cancer prevention and co-treatment. However, no single nutraceutical or food has been found to be completely effective against cancer. This could be due to the fact that cancer is a multifactorial disease, as it can be caused by several intrinsic factors (e.g., inherited mutations, hormones, immune conditions, and oxidative stress) and some environmental or extrinsic factors (e.g., tobacco, diet, radiation, and infectious organisms) [2]. Nutraceutical combinations could be a powerful solution, as they can act synergistically against chronic diseases, i.e., an effect greater than the sum of the effects of the individual compounds, by attacking different targets of the disease. Moreover, the combination of phytochemicals can interfere or activate different cell mechanisms by improving the bioavailability of active compounds, which leads to dose reduction and thereby a decrease of toxic effects, among other advantages [2]. Nutraceutical combinations can be used, 
therefore, to formulate novel and highly effective food products for the prevention and co-treatment of chronic diseases, including cancer.

Recently, we proposed a method for designing advanced food products against chronic diseases [2]. Briefly, it consists of the following sequential steps: (1) selecting the chronic disease; (2) selecting the nutraceutical candidates; (3) performing combination in vitro studies; (4) determining the best combination; (5) selecting food ingredients that are rich in the nutraceuticals of the best combination; (6) performing in vitro gastrointestinal digestion studies of the ingredients, to determine the bioavailability of the nutraceuticals; (7) performing combination studies of the digested ingredients based on the doses and proportions of the best combination, and if necessary, testing other combinations; (8) using the new information to design a highly effective food, beverage, or supplement for the prevention/co-treatment of the selected chronic disease; (9) testing in laboratory animals; (10) testing in clinical human trials; and (11) performing shelf-life studies. In the present study, we are undertaking the first four steps of this methodology, to find advanced nutraceutical combinations against colon cancer.

Colon cancer is the third most common (1.8 million cases) and the second death-causing cancer (over 800,000 deaths) [1]. Only $5-10 \%$ of colon cancers are due to genetic predisposition, while most of them are attributed to diet and lifestyle habits [3]. In addition, cancer is a multitarget disease, meaning that it can be attacked in several ways, such as inhibiting cell proliferation; inducing cell differentiation and apoptosis; and deterring angiogenesis and metastasis [4,5]. For these reasons, colon cancer is an excellent candidate for designing highly effective food products, using our proposed method.

Some nutraceuticals that have activity against colon cancer include curcumin, sulforaphane, and chlorogenic acid. Curcumin is a diphenolic compound and a yellow pigment from turmeric (Curcuma longa), the root of an Asian spice. Curcumin has been found to cause cell-cycle arrest, apoptosis, and invasion repression in different colon cancer cell lines [6-8]. In rodents, curcumin has shown beneficial effects against neoplastic lesions, macroscopic tumors, and aberrant crypt foci (ACF) $[9,10]$. ACF reduction has also been observed in humans [11]. Since curcumin is poorly absorbed in the human gastrointestinal tract, it has been recognized as an advantage for the management of colon cancer [11].

Sulforaphane is an isothiocyanate abundant in cruciferous vegetables [12]. Sulforaphane has inhibited the viability, proliferation, and angiogenesis of colon cancer cells [13-15]. Significant reduction of total $\mathrm{ACF}$, multicrypt foci, and mean tumor weight has also been achieved in animals [16,17]. Normally, sulforaphane is in the form of glucoraphanin, a glucosinolate; however, when the vegetable is macerated or eaten, the enzyme myrosinase hydrolyzes glucoraphanin to sulforaphane [12]. In the small intestine, sulforaphane is much better absorbed than glucoraphanin $[18,19]$. Cooking inactivates myrosinase, resulting in the ingestion of intact glucoraphanin. Then, glucoraphanin arrives into the colon and can be hydrolyzed to sulforaphane by the microbiota with thioglucosidase activity [12]. Thus, sulforaphane is another nutraceutical candidate against colon cancer.

Chlorogenic acid is one of the most studied phenolic compounds, widely distributed in plant foods [20]. Chlorogenic acid has also shown cytotoxic activity in colon cancer cells [21] and antitumoral activity in murine models [22]. However, chlorogenic acid is extensively metabolized by the human body, which may alter the activity observed in vitro, while the effects found in vivo could be caused by its metabolites. About $1 / 3$ of the ingested chlorogenic acid is readily absorbed in the small intestine [23] and further decomposed by the body, while the rest reaches the colon, where it is further metabolized by the colonic microbiome [24-26]. Dihydrocaffeic acid (3,4-dihydroxyhydrocinnamic acid, 3-(3,4-dihydroxyphenyl)propionic acid, hydrocaffeic acid) is one of the main metabolites of chlorogenic acid produced by the colonic microbiota. The anticancer potential of dihydrocaffeic acid against human cancer cell lines MCF-7 (breast), PC-3 (prostate), and HCT-116 (colon) has been recently reported [27]. Therefore, it is a relevant candidate for cancer prevention and treatment.

Nutraceutical combinations that have shown more potent effects than the individual compounds against colon cancer in vitro include sulforaphane and diindolylmethane [28]; indole-3-carbinol 
and genistein [29]; and polydatin and resveratrol [30]. Moreover, the combinations that have shown more potent effects in animals include curcumin and green tea catechins [31]; curcumin and epigallocatechin-3-gallate [32]; curcumin and resveratrol [33]; sulforaphane and dibenzoylmethane [34]; and diindolylmethane and butyrate [35]. Meanwhile, in humans, it has been reported that the combination of curcumin and quercetin exerted positive effects, but it was not established whether the combinations were more effective than the dosing of individual compounds [36].

The present study was undertaken to evaluate different combinations of curcumin, sulforaphane, and dihydrocaffeic acid over the viability of two different types of colon cancer cells, to find the best combination that can be further used to formulate advanced food products with anticancer properties.

\section{Results}

\subsection{Validation of Dose-Effect Data of Curcumin, Sulforaphane, Dihydrocaffeic Acid and Their Constant-Ratio Combinations}

The r-value of the linearized dose-effect curves (Equation (2), shown in Section 4.3 of Materials and Methods) for curcumin, sulforaphane, dihydrocaffeic acid, and their constant-ratio combinations are depicted in Table 1. All compounds and combinations had r-values $>0.95$ for both HT-29 and Caco-2 cancer cells; hence, the data were good enough to determine the type of effect (synergistic, additive, or antagonistic) by using the combination index (CI) method.

Table 1. R-values of linearized dose-effect curves of curcumin (C), sulforaphane (S), dihydrocaffeic acid (D), and their constant-ratio combinations.

\begin{tabular}{ccc}
\hline Cell Line & Nutraceutical/Combination (Proportions) & $\mathbf{r}$ \\
\hline HT-29 & C & $0.979 \pm 0.003$ \\
S & $0.989 \pm 0.002$ \\
D & $0.980 \pm 0.010$ \\
CD $(1: 1)$ & $0.989 \pm 0.004$ \\
SC $(1: 1)$ & $0.970 \pm 0.008$ \\
SD $(1: 1)$ & $0.984 \pm 0.014$ \\
Caco-2 & CSD(1:1:1) & $0.981 \pm 0.002$ \\
& S & $0.997 \pm 0.001$ \\
& D & $0.971 \pm 0.026$ \\
& CD $(1: 4)$ & $0.982 \pm 0.009$ \\
CD $(9: 2)$ & $0.952 \pm 0.004$ \\
& CSD(7:1:1) & $0.996 \pm 0.001$ \\
& & $0.986 \pm 0.002$ \\
\hline
\end{tabular}

\footnotetext{
Values represent the mean \pm standard error of two independent experiments performed on different days, with each experiment having three replicates. The equation to linearize the dose-effect curves was $\log (\mathrm{fa} / \mathrm{fu})=\mathrm{m} \log (\mathrm{D})-\mathrm{m} \log (\mathrm{Dm})$ [37], where $D=$ dose, $\mathrm{fa}=$ fraction of cells killed at dose $\mathrm{D}, \mathrm{fu}=$ fraction of unaffected cells by dose $\mathrm{D}, \mathrm{Dm}=\mathrm{CC}_{50}$ (cytotoxic concentration to kill $50 \%$ of cells), and $\mathrm{m}=$ coefficient that indicates the form of the dose-effect curve.
}

\subsection{Effects of Equimolar Combinations of Curcumin, Sulforaphane, and Dihydrocaffeic Acid on the Viability of HT-29 Colon Cancer Cells}

Dose-effect data of curcumin, sulforaphane, dihydrocaffeic acid, and the equimolar combinations curcumin-dihydrocaffeic acid(1:1) [CD(1:1)], sulforaphane-curcumin(1:1) [SC(1:1)], sulforaphanedihydrocaffeic acid(1:1) [SD(1:1)], and curcumin-sulforaphane-dihydrocaffeic acid [CSD(1:1:1)] were analyzed, to determine the effect on the viability of HT-29 cells, by calculating the CI values at $50 \%, 75 \%$, and $90 \%$ cytotoxicity level (Figure $1 \mathrm{~A}-\mathrm{C}$, respectively). At $50 \%$ and $75 \%$ cytotoxicity, the effects of CD, $\mathrm{SD}$, and CSD were nearly additive $(\mathrm{CI} \approx 1)$, while SC showed a relatively high antagonistic effect (CI between 2.5 and 3 ). However, at $90 \%$ cytotoxicity, SD exerted a significant synergistic effect $(C I \approx 0.70)$. The doses of the individual nutraceuticals, as well as the doses and dose-reduction index (DRI) values of the combinations at all cytotoxicity levels, are shown in Table 2. The synergistic combination SD at $90 \%$ cytotoxicity caused a $2 x$ dose reduction of sulforaphane and $10 x$ of dihydrocaffeic acid, whereas 
SC at all cytotoxicity levels showed a DRI $<1$, which means that the combination caused an increase in the dose needed to kill the cancer cells, making it antagonistic.


Figure 1. Combination index (CI) values of equimolar combinations of curcumin $(\mathrm{C})$, sulforaphane (S), and dihydrocaffeic acid (D) on the viability of HT-29 colon cancer cells at 50\% (A), 75\% (B), and 90\% (C) cytotoxicity levels. Values represent the mean \pm standard error of two independent experiments performed on different days, with each experiment having three replicates. Abbreviations: CI 50, 75, and $90=$ Combination index at $50 \%, 75 \%$, and $90 \%$ cytotoxicity. 
Table 2. Doses and dose-reduction index (DRI) values of curcumin (C), sulforaphane (S), dihydrocaffeic acid (D), and their equimolar combinations at different cytotoxicity levels of HT-29 colon cancer cells.

\begin{tabular}{|c|c|c|c|c|c|c|c|c|c|}
\hline \multirow{3}{*}{$\begin{array}{c}\text { Cytotoxicity Level } \\
\text { Compound } \\
\text { Individual dose }(\mu \mathrm{M})\end{array}$} & \multicolumn{3}{|c|}{$50 \%$} & \multicolumn{3}{|c|}{$75 \%$} & \multicolumn{3}{|c|}{$90 \%$} \\
\hline & $\mathrm{C}$ & $S$ & $\mathrm{D}$ & $\mathrm{C}$ & $S$ & $\mathrm{D}$ & $\mathrm{C}$ & $S$ & $\mathrm{D}$ \\
\hline & $31.6 \pm 4.2 \mathrm{~b}$ & $41.3 \pm 14.6 \mathrm{~b}$ & $188.4 \pm 9.4 a$ & $60.6 \pm 6.0 \mathrm{~b}$ & $81.9 \pm 29.4 b$ & $389.5 \pm 34.7 a$ & $116.3 \pm 7.5 b$ & $162.2 \pm 59.1 b$ & $806.2 \pm 103.5 a$ \\
\hline \multicolumn{10}{|l|}{ Combination dose $(\mu \mathrm{M})$} \\
\hline $\mathrm{CD}(1: 1)$ & $33.9 \pm 9.6 \mathrm{~b}$ & & $33.9 \pm 9.6 \mathrm{~b}$ & $59.0 \pm 14.6 \mathrm{~b}$ & & $59.0 \pm 14.6 b$ & $102.6 \pm 21.9 b$ & & $102.6 \pm 21.9 b$ \\
\hline $\mathrm{SC}(1: 1)$ & $46.5 \pm 10.0 \mathrm{~b}$ & $46.5 \pm 10.0 b$ & & $96.5 \pm 26.8 \mathrm{~b}$ & $96.5 \pm 26.8 b$ & & $200.7 \pm 68.2 b$ & $200.7 \pm 68.2 b$ & \\
\hline $\mathrm{SD}(1: 1)$ & & $40.9 \pm 4.7 \mathrm{~b}$ & $40.9 \pm 4.7 \mathrm{~b}$ & & $60.1 \pm 11.5 b$ & $60.1 \pm 11.5 b$ & & $88.8 \pm 23.5 b$ & $88.8 \pm 23.5 b$ \\
\hline $\operatorname{CSD}(1: 1: 1)$ & $19.4 \pm 7.4 \mathrm{~b}$ & $19.4 \pm 7.4 \mathrm{~b}$ & $19.4 \pm 7.4 \mathrm{~b}$ & $32.3 \pm 8.1 b$ & $32.3 \pm 8.1 \mathrm{~b}$ & $32.3 \pm 8.1 b$ & $55.0 \pm 6.0 \mathrm{~b}$ & $55.0 \pm 6.0 \mathrm{~b}$ & $55.0 \pm 6.0 \mathrm{~b}$ \\
\hline \multicolumn{10}{|l|}{ DRI } \\
\hline $\mathrm{CD}(1: 1)$ & $1.00 \pm 0.2 b$ & & $6.1 \pm 2.0 \mathrm{ab}$ & $1.1 \pm 0.2 b$ & & $7.2 \pm 2.4 \mathrm{ab}$ & $1.2 \pm 0.2 b$ & & $8.5 \pm 2.8 \mathrm{ab}$ \\
\hline $\mathrm{SC}(1: 1)$ & $0.7 \pm 0.1 b$ & $0.9 \pm 0.1 b$ & & $0.7 \pm 0.1 b$ & $0.8 \pm 0.1 b$ & & $0.6 \pm 0.2 b$ & $0.80 \pm 0.0 \mathrm{~b}$ & \\
\hline $\mathrm{SD}(1: 1)$ & & $1.00 \pm 0.2 b$ & $4.7 \pm 0.8 \mathrm{ab}$ & & $1.3 \pm 0.2 b$ & $6.8 \pm 1.9 \mathrm{ab}$ & & $1.8 \pm 0.2 b$ & $10.1 \pm 3.8 \mathrm{ab}$ \\
\hline $\operatorname{CSD}(1: 1: 1)$ & $1.8 \pm 0.5 \mathrm{ab}$ & $2.2 \pm 0.1 \mathrm{ab}$ & $11.6 \pm 4.9 \mathrm{a}$ & $2.00 \pm 0.3 b$ & $2.5 \pm 0.3 b$ & $13.2 \pm 4.4 \mathrm{a}$ & $2.1 \pm 0.1 b$ & $2.9 \pm 0.8 b$ & $15.1 \pm 3.5 \mathrm{a}$ \\
\hline
\end{tabular}

Values represent the mean \pm standard error of two independent experiments performed on different days, with each experiment having three replicates. Different letters in the same cytotoxicity level $(50 \%, 75 \%$, or $90 \%$ ) and quadrant (dose or DRI) indicate statistically significant difference by Tukey's test $(p<0.05)$. 
2.3. Effects of Equimolar Combinations of Curcumin, Sulforaphane, and Dihydrocaffeic Acid on the Viability of Caco-2 Colon Cancer Cells

The CI-values for the equimolar combinations of curcumin, sulforaphane, and dihydrocaffeic acid on the viability of Caco-2 cells at 50\%,75\%, and 90\% cytotoxicity level are illustrated in Figure 2A-C, respectively. All combinations were antagonistic at all cytotoxicity levels, and this antagonism tended to increase with increasing cytotoxicity.
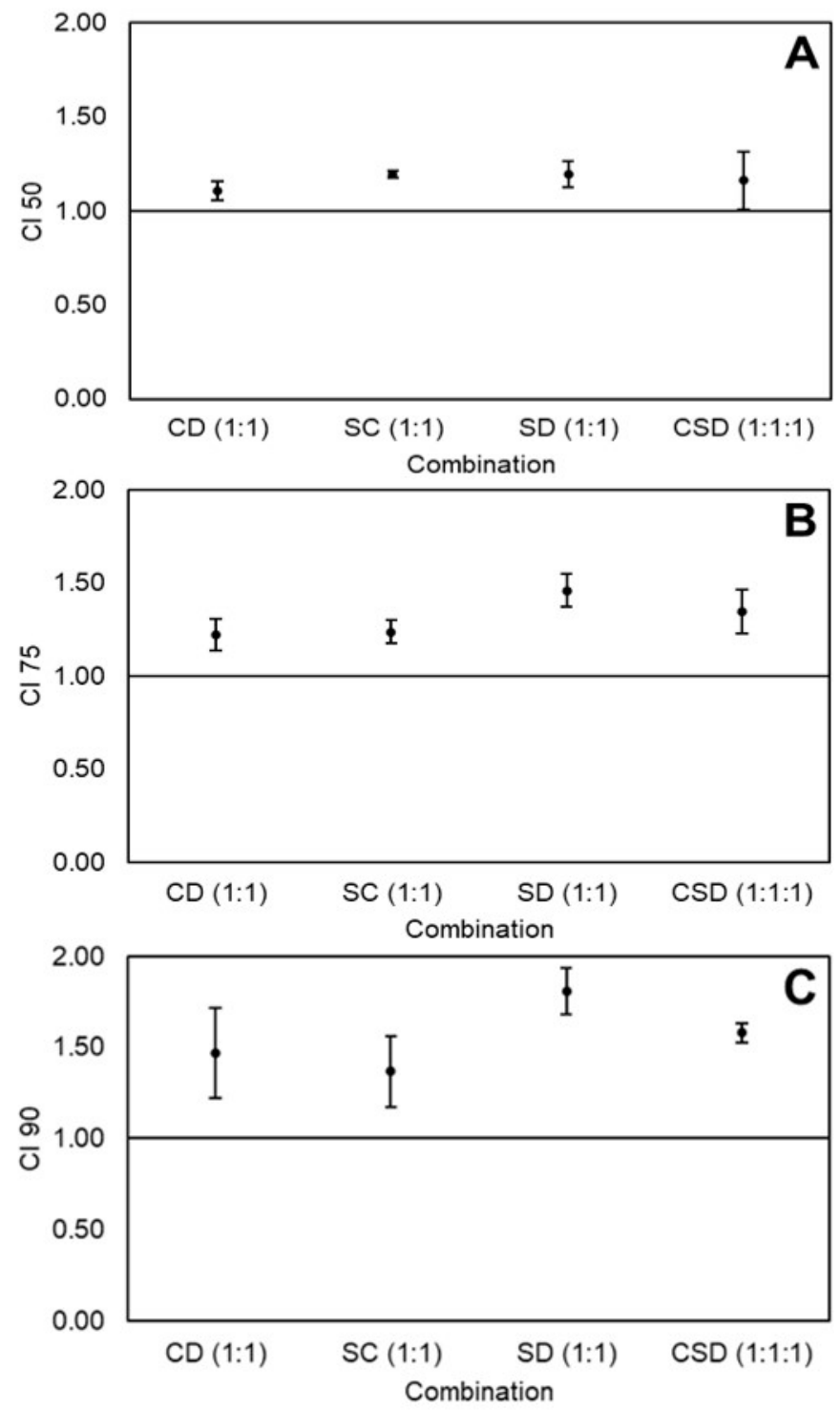

Figure 2. Combination index (CI) values of equimolar combinations of curcumin (C), sulforaphane (S), and dihydrocaffeic acid (D) on the viability of Caco-2 colon cancer cells at 50\% (A), 75\% (B), and 90\% (C) cytotoxicity levels. Values represent the mean \pm standard error of two independent experiments performed on different days, with each experiment having three replicates. Abbreviations: CI 50, 75, and $90=$ Combination index at 50\%, 75\%, and 90\% cytotoxicity.

2.4. Effects of Non-Equimolar Combinations of Curcumin, Sulforaphane, and Dihydrocaffeic Acid on the Viability of Caco-2 Cancer Cells

Since no synergistic combinations were detected in Caco-2 cells using equimolar combinations, a prescreening of different single-dose, non-equimolar combinations was performed (Table 3 ). The mixtures $\operatorname{CD}(1: 4), \operatorname{CD}(9: 2)$, and $\operatorname{CSD}(7: 1: 1)$ showed synergy at relatively high cytotoxicity levels (50-65\%). Hence, these combinations were thoroughly analyzed. 
Table 3. Preliminary combination index (CI) values of non-equimolar combinations of curcumin (C), sulforaphane (S), and dihydrocaffeic acid (D) on the viability of Caco-2 colon cancer cells.

\begin{tabular}{ccccc}
\hline Combination & Doses $(\boldsymbol{\mu M})$ & Proportions & Cytotoxicity Level (\%) & CI \\
\hline CD & $45: 10$ & $9: 2$ & 64 & $\mathbf{0 . 7 9} \pm \mathbf{0 . 0 1 g}$ \\
& $35: 20$ & $7: 4$ & 15 & $1.41 \pm 0.36 \mathrm{efg}$ \\
SC & $20: 80$ & $1: 4$ & 52 & $\mathbf{0 . 8 8} \pm \mathbf{0 . 0 2 f g}$ \\
& $30: 10$ & $5: 1$ & 35 & $2.63 \pm 0.09 \mathrm{bc}$ \\
SD & $25: 5$ & $2: 7$ & 29 & $2.31 \pm 0.15 \mathrm{bcd}$ \\
& $10: 35$ & $3: 1$ & 34 & $1.58 \pm 0.15 \mathrm{ef}$ \\
& $30: 10$ & $3: 2$ & 25 & $2.90 \pm 0.19 \mathrm{~b}$ \\
CSD & $15: 10$ & $3: 16$ & 5 & $2.80 \pm 0.40 \mathrm{~b}$ \\
& $15: 80$ & $7: 1: 1$ & 62 & $1.66 \pm 0.10 \mathrm{de}$ \\
& $35: 5: 5$ & $3: 1: 16$ & 5 & $\mathbf{0 . 9 0} \pm \mathbf{0 . 0 7 f g}$ \\
& $15: 5: 80$ & $1: 5: 1$ & 38 & $3.70 \pm 0.52 \mathrm{a}$ \\
& $5: 25: 5$ & & $2.06 \pm 0.05 \mathrm{cde}$ \\
\hline
\end{tabular}

Values represent the mean \pm standard error of two independent experiments performed on different days, with each experiment having three replicates. Different letters indicate statistically significant difference by Tukey's test $(p<0.05)$. Synergistic combinations are highlighted in bold.

Validated CI-values of combinations $\operatorname{CD}(1: 4), \operatorname{CD}(9: 2)$, and $\operatorname{CSD}(7: 1: 1)$ at $50 \%, 75 \%$, and $90 \%$ cytotoxicity levels are depicted in Figure $3 \mathrm{~A}-\mathrm{C}$, respectively. $\mathrm{CD}(1: 4)$ had a strong synergistic effect at all cytotoxicity levels (CI 0.25-0.5). Interestingly, the $\mathrm{CD}(9: 2)$ combination showed nearly additive effects at $50 \%$ and $75 \%$ cytotoxicity levels, and synergistic effects at $90 \%$ cytotoxicity. Meanwhile, $\operatorname{CSD}(7: 1: 1)$ had an opposite tendency, starting at synergy at 50\% cytotoxicity and moving to antagonism at $90 \%$ cytotoxicity. The doses of the individual nutraceuticals, as well as the doses and DRI values of the combinations at all cytotoxicity levels are shown in Table 4 . The synergistic effects of $C D(1: 4)$ caused 4-7x dose reductions of both curcumin and dihydrocaffeic acid. On the other hand, $\operatorname{CD}(9: 2)$ caused large dose reductions of dihydrocaffeic acid (17-25x) at all cytotoxicity levels; however, almost no dose reduction of curcumin was observed (DRI $\approx 1$ ), explaining why most effects were additive. Likewise, although important dose reductions of sulforaphane (2.5-7x) and dihydrocaffeic acid (30-40x) were observed at all levels due to the $\operatorname{CSD}(7: 1: 1)$ combination, curcumin showed only small dose reductions at $50 \%$ and $75 \%$ cytotoxicity (DRI $\approx 1$ ) and a small dose increase at $90 \%$ cytotoxicity $(\mathrm{DRI}<1)$, explaining the tendency from synergy to antagonism.

\subsection{Determination of Best Combination}

The cytotoxicity of the synergistic combinations $\mathrm{SD}(1: 1), \mathrm{CD}(1: 4)$, and $\mathrm{CD}(9: 2)$ was compared between the colon cancer cells and healthy fetal human colon (FHC) cells at 50\%, 75\%, and 90\% cytotoxicity levels (Figure 4A-C, respectively). SD(1:1) was significantly more cytotoxic for cancer cells than healthy cells at all cytotoxicity levels. No significant differences in cytotoxicity were found between the three cell lines with $\mathrm{CD}(1: 4)$. Meanwhile, $\mathrm{CD}(9: 2)$ was significantly more cytotoxic for healthy cells than cancer cells, particularly at high cytotoxicity levels (75\% and 90\%). Based on this information, $\mathrm{SD}(1: 1)$ was chosen as the best combination. 

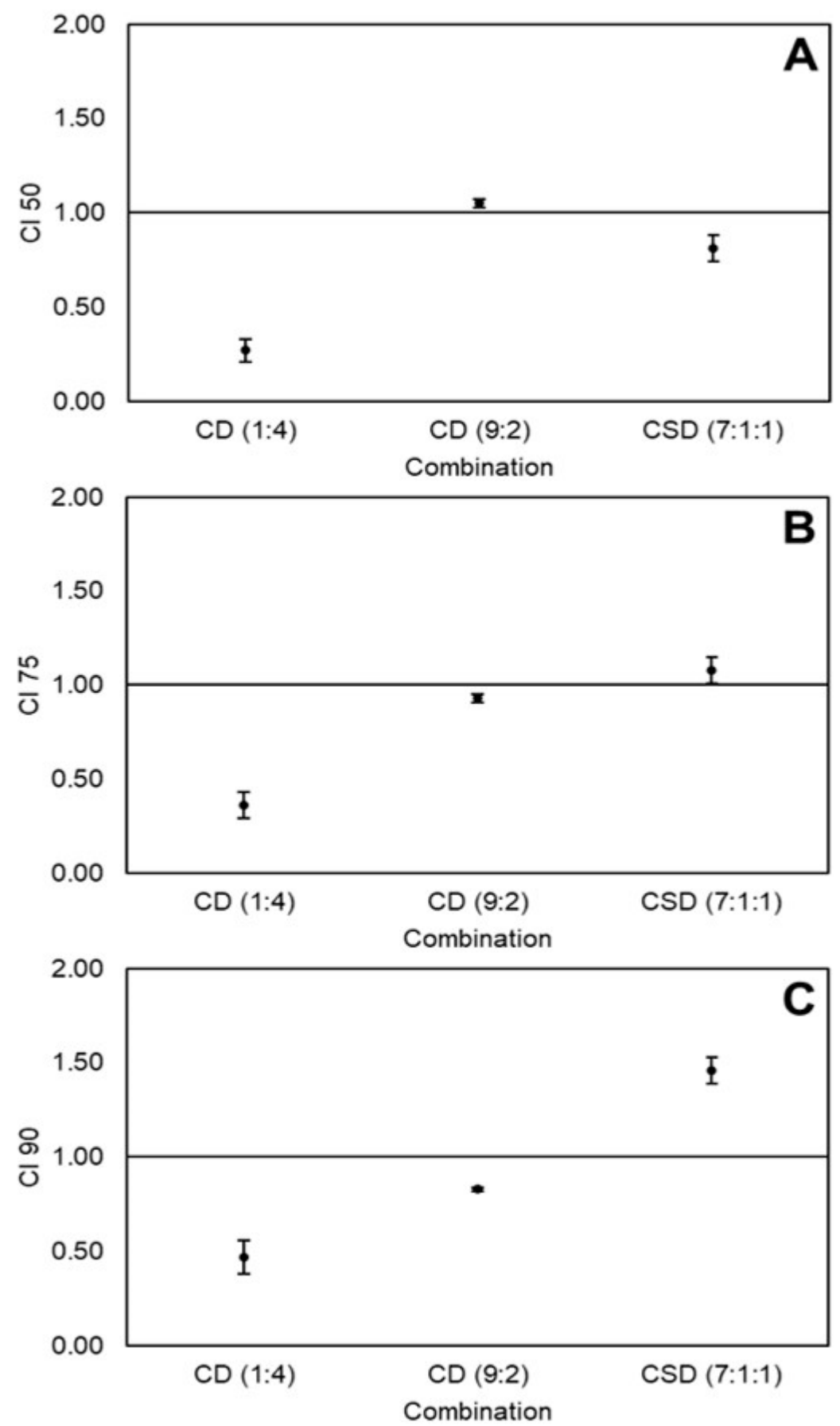

Figure 3. Combination index (CI) values of non-equimolar combinations of curcumin (C), sulforaphane (S), and dihydrocaffeic acid (D) on the viability of Caco-2 colon cancer cells at $50 \%$ (A), $75 \%$ (B), and $90 \%$ (C) cytotoxicity levels. Values represent the mean \pm standard error of two independent experiments performed on different days, with each experiment having three replicates. Abbreviations: CI 50, 75, and $90=$ Combination index at 50\%,75\%, and 90\% cytotoxicity. 
Table 4. Doses and dose-reduction index (DRI) values of curcumin (C), sulforaphane (S), dihydrocaffeic acid (D), and their non-equimolar combinations at different cytotoxicity levels of Caco-2 colon cancer cells.

\begin{tabular}{|c|c|c|c|c|c|c|c|c|c|}
\hline \multirow{3}{*}{$\begin{array}{c}\text { Cytotoxicity Level } \\
\text { Compound } \\
\text { Individual dose }(\mu \mathrm{M})\end{array}$} & \multicolumn{3}{|c|}{$50 \%$} & \multicolumn{3}{|c|}{$75 \%$} & \multicolumn{3}{|c|}{$90 \%$} \\
\hline & C & $S$ & D & C & $S$ & D & C & $S$ & D \\
\hline & $65.8 \pm 2.3 b$ & $44.6 \pm 2.6 b c$ & $248.0 \pm 11.7 \mathrm{a}$ & $94.6 \pm 2.7 \mathrm{~b}$ & $48.7 \pm 2.5 \mathrm{~cd}$ & $386.8 \pm 3.6 \mathrm{a}$ & $135.9 \pm 2.9 \mathrm{bc}$ & $53.2 \pm 2.5 \mathrm{cde}$ & $605.3 \pm 39.8 \mathrm{a}$ \\
\hline Combination dose $(\mu \mathrm{M})$ & & & & & & & & & \\
\hline $\mathrm{CD}(1: 1)$ & $8.8 \pm 2.2 \mathrm{e}$ & & $35.3 \pm 8.8 \mathrm{cde}$ & $17.2 \pm 3.6 \mathrm{de}$ & & $68.7 \pm 14.5 \mathrm{bc}$ & $33.5 \pm 5.8 \mathrm{de}$ & & $134.0 \pm 23.2 b c$ \\
\hline $\mathrm{SC}(1: 1)$ & $65.4 \pm 3.6 \mathrm{~b}$ & & $14.5 \pm 0.8 \mathrm{de}$ & $83.6 \pm 3.7 \mathrm{~b}$ & & $18.6 \pm 0.8 \mathrm{de}$ & $106.9 \pm 3.5 \mathrm{bcd}$ & & $23.8 \pm 0.8 \mathrm{de}$ \\
\hline $\operatorname{CSD}(1: 1: 1)$ & $42.7 \pm 5.6 \mathrm{bcd}$ & $6.1 \pm 0.8 \mathrm{e}$ & $6.1 \pm 0.8 \mathrm{e}$ & $78.0 \pm 7.9 \mathrm{bc}$ & $11.1 \pm 1.1 \mathrm{e}$ & $11.1 \pm 1.1 \mathrm{e}$ & $142.6 \pm 10.1 \mathrm{~b}$ & $20.4 \pm 1.4 \mathrm{e}$ & $20.4 \pm 1.4 \mathrm{e}$ \\
\hline DRI & & & & & & & & & \\
\hline $\mathrm{CD}(1: 1)$ & $7.89 \pm 1.71 c$ & & $7.41 \pm 1.52 \mathrm{c}$ & $5.73 \pm 1.06 c$ & & $5.91 \pm 1.30 \mathrm{c}$ & $4.17 \pm 0.63 b$ & & $4.71 \pm 1.11 b$ \\
\hline $\mathrm{SC}(1: 1)$ & $1.01 \pm 0.02 c$ & & $17.07 \pm 0.15 b$ & $1.13 \pm 0.02 c$ & & $20.87 \pm 1.12 b$ & $1.27 \pm 0.01 b$ & & $25.56 \pm 2.51 \mathrm{a}$ \\
\hline $\operatorname{CSD}(1: 1: 1)$ & $1.56 \pm 0.15 c$ & $7.37 \pm 0.55 c$ & $41.07 \pm 3.49 a$ & $1.22 \pm 0.09 c$ & $4.39 \pm 0.22 c$ & $35.09 \pm 3.88 \mathrm{a}$ & $0.96 \pm 0.05 b$ & $2.62 \pm 0.06 b$ & $30.00 \pm 4.08 \mathrm{a}$ \\
\hline
\end{tabular}

Values represent the mean \pm standard error of two independent experiments performed on different days, with each experiment having three replicates. Different letters in the same cytotoxicity level $(50 \%, 75 \%$, or $90 \%)$ and quadrant (dose or DRI) indicate statistically significant difference by Tukey's test $(p<0.05)$. 



Figure 4. Cytotoxicity of synergistic combinations of curcumin (C), sulforaphane (S), and dihydrocaffeic acid (D) on colon cancer cells (HT-29 and Caco-2) and healthy colon cells (FHC). (A) SD(1:1), (B) CD(1:4), and $(C) C D(9: 2)$. Values represent the mean \pm standard error of two independent experiments performed on different days, with each experiment having three replicates. Different letters in the same cytotoxicity level indicate statistically significant difference by Tukey's test $(p<0.05)$.

\section{Discussion}

\subsection{Some General Aspects about Cell Cycle and Apoptosis}

Results herein demonstrated that the combination SD(1:1) was synergistic against HT-29 colon cancer cells at 90\% cytotoxicity level (Figure 1), using relatively high doses (90:90 $\mu \mathrm{M}$, Table 2). Likewise, the $\mathrm{CD}(1: 4)$ combination was synergistic at all cytotoxicity levels (doses 9:36-34:136 $\mu \mathrm{M}$, Table 4) and the combination $\mathrm{CD}(9: 2)$ at 90\% cytotoxicity level (doses 108:24 $\mu \mathrm{M}$, Table 4) against Caco-2 colon cancer cells (Figure 3). Synergy can occur when two compounds cooperate on targets on the same 
or different pathways involved in the same process [2,38]. In order to understand the mechanisms through which $\mathrm{SD}(1: 1), \mathrm{CD}(1: 4)$, and $\mathrm{CD}(9: 2)$ exerted the synergistic effect against the viability of colon cancer cells, some aspects about the cell cycle and apoptosis need to be addressed.

Many molecules and metabolic pathways are involved in cell cycle and apoptosis. Mitogen-activated protein kinases (MAPKs) belong to the superfamily of serine/threonine kinases, which play a central role in transducing various extracellular signals into the nuclei and regulate a variety of physiological processes, including cell growth, differentiation, cell cycle, and apoptosis. The extracellular-regulated kinase (ERK), c-jun N-terminal kinase (JNK), and p38 are the three most relevant MAPK pathways. The ERK pathway is generally believed to be prosurvival, while JNK and p38 are often considered as apoptotic [15]. Moreover, cyclins are a major group of proteins that control the cell cycle. Downregulation of cyclin D1 has been found to cause $\mathrm{G}_{1}$-phase cell-cycle arrest [39], while induction of cyclins $A$ and $B 1$ causes $G_{2} / M$ phase arrest [40]. In addition, it is known that p21 is an inhibitor of cell proliferation by restraining cyclin-dependent kinases (CDKs) [41]. Activation of the ERK and p38 pathways is involved in the upregulation of p21, whereas the activation of the JNK pathway is involved in the downregulation of cyclin D1 [39].

Furthermore, a major pathway through which apoptosis can be triggered is the mitochondriadependent intrinsic pathway. Two main groups are involved in this pathway: the Bcl-2 family proteins and the caspase family. The Bcl-2 family is subdivided into three groups: the BH3-only proteins (e.g., Bid, Bad, Bik, Bim, Noxa, and Puma), the pro-apoptotic Bax subfamily (e.g., Bax, Bak, and Bok), and the anti-apoptotic Bcl-2 subfamily (e.g., Bcl-2 and Bcl-XL). On the other hand, caspases are cysteine aspartyl-specific proteases that regulate the initiation and final execution of apoptosis. In response to death stimuli (e.g., DNA damage), BH3-only proteins either activate the Bax members or antagonize the Bcl-2 members, which causes mitochondrial outer membrane permeabilization and consequently the release of cytochrome $c$ into the cytoplasm. Cytochrome $c$ then binds with apoptosis protease activating factor-1 (Apaf-1). Seven Apaf-1/cytochrome $c$ complexes assemble to form the apoptosome in the presence of ATP/dATP. Then the apoptosome recruits inactive procaspase-9, facilitating its autocleavage into its active form caspase-9. Still bound to the apoptosome, caspase-9 subsequently activates caspase-3, and caspase- 3 initiates a caspase cascade that leads finally to apoptosis [8,42-44].

Mitochondria have an outer membrane and an inner membrane, which are both key in the induction of apoptosis. The voltage-dependent anion channel (VDAC) is the most abundant protein of the outer membrane and is normally responsible for the transport of metabolites between the cytoplasm and the mitochondrial intermembrane space. Meanwhile, adenine nucleotide translocator (ANT) is the most abundant protein of the inner membrane and is a strictly specific antiporter that only exchanges ATP and ADP. When death stimuli activate proapoptotic proteins, such as Bax, they can interact with VDAC and ANT to form sufficiently large channels to release cytochrome $c$ and initiate apoptosis. In addition, mitochondria are some of the intracellular components that produce reactive oxygen species (ROS) in a natural, controlled manner. However, when there is an excess of ROS (which can be caused, for instance, by cytotoxic agents), these species can interact directly with VDAC and ANT to facilitate pore opening and consequently cytochrome $c$ release, ending in apoptosis [45].

3.2. Mechanisms of Sulforaphane and Dihydrocaffeic Acid against Colon Cancer Cells, and Proposed Model of SD(1:1) Synergy against HT-29

To fully understand how the combination SD(1:1) exerted a synergistic effect against HT-29 colon cancer cells, the different mechanisms of action of sulforaphane and dihydrocaffeic acid are described.

Previous reports have demonstrated that sulforaphane has several effects against HT-29. At a dose of $15 \mu \mathrm{M}$, sulforaphane caused cell-cycle arrest at $\mathrm{G}_{2} / \mathrm{M}$ phase and apoptosis in a dose-dependent manner in HT-29 [40]. Cell-cycle arrest was associated with an increase in the expression of cyclins A and B1, while apoptosis with an increase in proapoptotic protein Bax (but no effect on anti-apoptotic protein $\mathrm{Bcl}-2)$, and the release of cytochrome $c$ from the mitochondria. Moreover, at high doses $(>25 \mu \mathrm{M})$, 
sulforaphane dramatically induced in HT-29 the expression of p21 and inhibited the expression of cyclin $D 1$, leading to cell-cycle arrest at $G_{1}$ phase [39]. Additionally, the authors observed that sulforaphane activated several MAPK pathways, including ERK, JNK, and p38. They related all these effects with sulforaphane-induced oxidative stress. Since synergy was obtained at high doses of sulforaphane $(90 \mu \mathrm{M})$ in our study, it is more likely that the mechanism of sulforaphane was similar to the one reported by Shen et al. [39].

Meanwhile, the anticancer mechanisms of dihydrocaffeic acid are unknown. It can be hypothesized, however, that the mechanisms are similar to caffeic acid, since they have almost identical chemical structures [27]. Jaganathan [46] reported an increase in ROS by caffeic acid in HCT 15 colon cancer cells, which caused a reduction in mitochondrial membrane potential and consequently apoptosis. Although it may seem paradoxical that an antioxidant such as caffeic acid can cause oxidative damage, several antioxidants follow a hormetic mechanism, where, at low concentrations, the compound can work as an antioxidant, but at high concentrations, it becomes prooxidant [47]. Dihydrocaffeic acid is mostly recognized as an antioxidant [48]. Hence, the mode of action of dihydrocaffeic acid could be a hormetic mechanism, where, at high doses, it causes oxidative damage, causing mitochondrial dysfunction and apoptosis. In fact, this explains why dihydrocaffeic acid required much higher doses, individually, to terminate colon cancer cells, compared with curcumin and sulforaphane (Tables 2 and 4).

Since the combination $\mathrm{SD}(1: 1)$ was chosen as the best (Section 2.5), we proposed a detailed model to explain the synergy of this combination against HT-29 based on the reported mechanisms (Figure 5). Briefly, sulforaphane and dihydrocaffeic acid synergistically enhanced ROS production. The high amount of ROS unleashed a chain of events, including activation of ERK, JNK, and p38 MAPK pathways, which in turn induced p21 and downregulated cyclin D1, causing cell-cycle arrest at $\mathrm{G}_{1}$ phase. Simultaneously, ROS acted on the VDAC and ANT proteins of the outer and inner mitochondria membranes, respectively, facilitating pore opening and subsequent cytochrome $c$ release, resulting in the activation of the apoptotic intrinsic pathway.

\subsection{Mode of Action of Curcumin against Colon Cancer Cells, and Proposed Mechanisms of CD(1:4) and $C D(9: 2)$ Synergy against Caco-2}

Curcumin exerts several effects against colon cancer cell lines. Jaiswal et al. [6] reported induction of caspase-3-mediated $\beta$-catenin cleavage, degradation of E-cadherin and APC. Moreover, curcumin decreased transactivation of the $\beta$-catenin/Tcf-Lef complex and the promoter DNA-binding activity of the $\beta$-catenin/Tcf-Lef complex, downregulating c-myc and cdc2/cyclin B1 kinase activity in HCT-116 cells. These mechanisms were linked to alteration of the cell-cell adhesion pathway, p53- and p21-independent $G_{2} / M$ phase arrest, and apoptosis. Curcumin also caused apoptosis of HCT-116 by sustained phosphorylation and activation of the JNK pathway, induction of JNK-dependent phosphorylation of c-jun, expression of AP-1, and inhibition of constitutive NF- $\mathrm{KB}$ [49]. The importance of Bax in curcumin-induced apoptosis of HCT-116 was studied by Rashmi et al. [44]. Cells with one allele of Bax gene (Bax+/-) treated with curcumin showed decreased viability, activation of caspases 3 and 9, release of cytochrome $c$, and expression of second mitochondria derived activator of caspase (Smac) and apoptosis-inducing factor (AIF), whereas cells with Bax knockout (Bax-/-) were not affected. However, downregulation of the antiapoptotic protein Bcl-XL or overexpression of Smac caused apoptosis of Bax-/- cells after curcumin treatment, offering an alternative against Bax-deficient chemoresistant cancers. In addition, curcumin caused apoptosis in HT-29 cells by activating the expression of caspases 3 and 12, and furthermore through the involvement of calpain [8]. Finally, Goel et al. [50] found that curcumin inhibited cell growth of HT-29 through inhibition of cyclooxygenase-2 (COX-2). Hence, the synergistic effects of $\mathrm{CD}(1: 4)$ and $\mathrm{CD}(9: 2)$ against the viability of Caco-2 could be due to the multitarget anticancer activity of curcumin plus ROS generation by dihydrocaffeic acid, as proposed in Section 3.2. 




Figure 5. Hypothetical model of the synergistic mechanism of sulforaphane and dihydrocaffeic acid against the viability of HT-29 colon cancer cells. Black arrows represent metabolic pathways, whereas blue arrows indicate up- or downregulation of proteins. Sulforaphane and dihydrocaffeic acid work together to enhance reactive oxygen species (ROS) production to levels that cannot be reached by either compound alone. ROS activate the mitogen-activated protein kinase (MAPK) pathways extracellular-regulated kinase (ERK), c-jun N-terminal kinase (JNK), and p38. ERK and p38 upregulate p21, while JNK downregulates cyclin D1. The result of these events is cell-cycle arrest at G1 phase. Simultaneously, ROS attacks mitochondria, specifically the voltage-dependent anion channel (VDAC) and adenine nucleotide translocator (ANT) proteins, which are located in the outer and inner membranes, respectively. This facilitates pore opening, causing the release of cytochrome $c(C)$ into the cytoplasm. Then, cytochrome $c$ initiates the apoptotic intrinsic pathway, where (1) cytochrome $c$ binds with apoptosis protease activating factor-1 (Apaf-1) to form a binary complex; (2) seven Apaf-1/cytochrome $c$ complexes assemble to form the apoptosome; and (3) the apoptosome recruits inactive procaspase-9 (Pcsp-9), facilitating its autocleavage into its active form caspase-9 (Csp-9). Csp-9, still bound to the apoptosome, cleaves procaspase-3 (Pcsp-3) into its active form caspase-3 (Csp-3). Finally, Csp-3 initiates a caspase cascade (Csp cascade) that leads to apoptosis.

\subsection{Different Effects of Same Combinations between Colon Cancer Cell Lines}

Different effects of the same combinations were observed when HT-29 and Caco-2 cells were compared. For instance, some of the equimolar combinations were additive or synergistic in HT-29 cells, whereas all equimolar combinations were antagonistic in Caco-2 cells (Figures 1 and 2). Different responses to nutraceutical combinations between cancer cell lines could be due to differences in their genetic profiles, which may lead to differences in the metabolism rate of the compounds, expression 
of detoxifying enzymes, and efficacy of the multidrug resistance system to pump out cytotoxic compounds [47].

\subsection{Different Effects of Varying Doses and Proportions of the Same Nutraceuticals in Colon Cancer Cells}

Different doses and proportions of the same nutraceuticals caused different effects in HT-29 and Caco- 2 cells. For instance, SD(1:1) caused an antagonistic effect at low doses ( $50 \%$ cytotoxicity level) but a synergistic effect at high doses (90\% cytotoxicity level) in HT-29 cells (Figure 1). Meanwhile, CD(1:1) was antagonistic at all cytotoxicity levels in Caco-2 cells (Figure 2), but changing the ratio to $\mathrm{CD}(1: 4)$ caused a synergistic effect at all studied cytotoxicity levels (Figure 3). A possible explanation could be that, at different doses and proportions, different mechanisms are activated [28]. This phenomenon has been observed with sulforaphane, where at low doses, it induced the expression of phase II detoxifying enzymes, while at high doses, it caused cell-cycle arrest and apoptosis in Caco-2 cells [51].

\subsection{Selectivity of Synergistic Combinations between Healthy and Colon Cancer Cells}

The cytotoxicity of the three synergistic combinations studied herein $(\mathrm{SD}(1: 1), \mathrm{CD}(1: 4)$, and $\mathrm{CD}(9: 2))$ was compared between healthy (FHC) and colon cancer cells (HT-29 and Caco-2), to see if there was at least one combination that was more selective toward the malignant cells (Figure 4). The CD(1:4) and $\mathrm{CD}(9: 2)$ combinations were similarly or even more cytotoxic for healthy cells than cancer cells (Figure $4 B, C$ ), suggesting that both mixtures attacked targets that were present in both healthy and cancer cells. Interestingly, the SD(1:1) combination was more selective toward both cancer cells than healthy cells at all cytotoxicity levels (Figure 4A). Sulforaphane has been reported to inhibit significantly more the cell proliferation of HCT-116 colon cancer cells than normal colon mucosa-derived (NCM460) cells, and to activate survival signaling in NCM460 and apoptotic signaling in HCT-116 cells [15]. In the case of oxidative stress, it is known that cancer cells consume higher amounts of oxygen than their healthy counterparts, in order to generate the necessary energy to upregulate multiple signaling pathways that promote proliferation, inhibit apoptosis, and promote migration and invasion of other tissues [47]. This comparatively higher oxygen consumption causes cancer cells to have a higher oxidative stress level than healthy cells. This important difference increases their survival potential, as larger amounts of ROS augment the probability of inducing mutations and redox signaling that inactivate apoptotic genes and activate prosurvival genes [52]. Therefore, the higher sensitivity of colon cancer cells to $\mathrm{SD}(1: 1)$ could be attributed to a combination of the selectivity of sulforaphane toward colon cancer cells and a greater oxidative damage caused by an initial higher oxidative status plus ROS generated by sulforaphane and dihydrocaffeic acid.

\section{Materials and Methods}

\subsection{Materials}

Curcumin, sulforaphane, dihydrocaffeic acid, dimethyl sulfoxide (DMSO), human recombinant epidermal growth factor (EGF), HEPES, cholera toxin, insulin, transferrin, and hydrocortisone were obtained from Merck (Kenilworth, NJ, USA). Dulbecco's Modified Eagle Medium/Nutrient Mixture F-12 (DMEM/F12), McCoy's 5A medium, human colon cancer cell lines Caco-2 (HTB-37) and HT-29 (HTB-38), and FHC healthy colon cells were purchased from American Type Culture Collection (ATCC, Manassas, VA, USA). Antibiotic-antimycotic (Anti-Anti) solution (10,000 U/mL penicillin, $10,000 \mu \mathrm{g} / \mathrm{mL}$ streptomycin, and $25 \mu \mathrm{g} / \mathrm{mL}$ amphotericin B) and fetal bovine serum (FBS) were acquired from Gibco Invitrogen (Carlsbad, CA, USA). CellTiter $96^{\circledR}$ AQueous One Solution Proliferation Assay kit was purchased from Promega (Madison, WI, USA).

\subsection{Cell Culture}

Caco-2 and HT-29 cells were grown in DMEM/F12 and McCoy's media, respectively. FHC were grown in DMEM/F12 supplemented with $25 \mathrm{mM} \mathrm{HEPES,} 10 \mathrm{ng} / \mathrm{mL}$ cholera toxin, $0.005 \mathrm{mg} / \mathrm{mL}$ insulin, 
$0.005 \mathrm{mg} / \mathrm{mL}$ transferrin, $100 \mathrm{ng} / \mathrm{mL}$ hydrocortisone, and $20 \mathrm{ng} / \mathrm{mL}$ EGF. All media were supplemented with $10 \%$ FBS and adjusted to $\mathrm{pH}$ 7.4. Cells were maintained at $80-90 \%$ confluency in tissue culture Petri dishes and incubated in a humidified incubator at $37{ }^{\circ} \mathrm{C}$ and $5 \% \mathrm{CO}_{2}$. Culture medium was changed every 3 days.

\subsection{Combination Studies}

Curcumin, sulforaphane, and dihydrocaffeic acid were tested, individually and in different combinations, over the viability of Caco-2 and HT-29 cells. All possible combinations were evaluated, i.e., $\mathrm{CD}, \mathrm{SC}, \mathrm{SD}$, and the triple combination CSD. To determine synergistic, additive, and antagonistic effects of the combinations, the CI method was used [37], which consists of the following equation:

$$
\left(\mathrm{CI}_{\mathrm{x}}\right)_{\mathrm{n}}=\sum_{\mathrm{j}=1}^{\mathrm{n}} \frac{(\mathrm{D})_{\mathrm{j}}}{\left(\mathrm{D}_{\mathrm{x}}\right)_{\mathrm{j}}}
$$

where (CIx) $\mathrm{n}$ is the combination index for $\mathrm{n}$ compounds (in this case, nutraceuticals) that achieve effect $x$ (in this case, \% cytotoxicity), (D) $j$ is the dose of each nutraceutical in the mixture that achieves effect $x$, and (Dx)j is the individual dose of each nutraceutical that produces the same effect $x$. The effects chosen were the cytotoxic concentrations to reduce the cell viability by $50 \%, 75 \%$, and $90 \%\left(\mathrm{CC}_{50}\right.$, $\mathrm{CC}_{75}$, and $\mathrm{CC}_{90}$, respectively). The CI-value determines the type of effect. If $\mathrm{CI}<1,=1$, or $>1$, then the combination is considered synergistic, additive, or antagonistic, respectively.

The CompuSyn software (version 1.0) was used to process the dose-effect data. For all individual nutraceuticals and constant-ratio combinations used, 6-point dose-effect curves were constructed and linearized, using the following equation:

$$
\log (\mathrm{fa} / \mathrm{fu})=\mathrm{m} \log (\mathrm{D})-\mathrm{m} \log \left(\mathrm{D}_{\mathrm{m}}\right)
$$

where $\mathrm{D}=$ dose, $\mathrm{fa}=$ fraction of cells killed at dose $\mathrm{D}, \mathrm{fu}=$ fraction of unaffected cells by dose $\mathrm{D}$ $(\mathrm{fu}=1-\mathrm{fa}), \mathrm{D}_{\mathrm{m}}=\mathrm{CC}_{50}$, and $\mathrm{m}=$ coefficient that indicates the form of the dose-effect curve (hyperbolic: $\mathrm{m}=1$, sigmoidal: $\mathrm{m}>1$, and flat sigmoidal: $\mathrm{m}<1$ ). The software was firstly used to validate that the data were good enough to be analyzed with the CI method. According to Chou [37], the data are valid if $r>0.95$ for individual compounds and constant-ratio combinations in vitro, using Equation (2). Once the data were validated, the software was used to calculate the CI-values, the individual and combined doses, and the DRI (a measure of how many times the dose of a compound is reduced due to a combination) at $\mathrm{CC}_{50}, \mathrm{CC}_{75}$, and $\mathrm{CC}_{90}$.

To minimize the number of combinations that need to be tested for finding synergistic combinations, equimolar combinations were done first (1:1 or 1:1:1). If no synergistic combinations were found (i.e., no combinations gave $\mathrm{CI}<1$ ), then non-equimolar combinations were assayed. The latter was done by first performing a prescreening, using 6-point dose-effect curves of the individual compounds and three single-dose combinations at different non-equimolar proportions for each type of combination (CD, SC, SD, and CSD). The doses and proportions of each non-equimolar combination were selected based on the $\mathrm{CC}_{50}$ values of the individual compounds. Briefly, the individual dose $((\mathrm{Dx}) \mathrm{j}$ value of Equation (1)) of each nutraceutical was substituted with its corresponding $\mathrm{CC}_{50}$ value, and then the dose of each nutraceutical in combination ((D)j value) was chosen, using two criteria. (1) The (D)j values should give a $\mathrm{CI}<1$, as illustrated in Equation (3):

$$
\frac{\mathrm{D}_{1}}{\left(\mathrm{CC}_{50}\right)_{1}}+\frac{\mathrm{D}_{2}}{\left(\mathrm{CC}_{50}\right)_{2}}+\frac{\mathrm{D}_{3}}{\left(\mathrm{CC}_{50}\right)_{3}}<1
$$

where $\left(\mathrm{CC}_{50}\right)_{1,2,3}$ and $\mathrm{D}_{1,2,3}$ are the $\mathrm{CC}_{50}$ and the dose in combination of nutraceuticals 1,2 , and 3 , respectively. (2) For each type of combination, there should be at least one non-equimolar combination where each of the nutraceuticals predominates (e.g., for combination type $C D$, there should be at least 
one combination where $C$ predominates, and another combination where $\mathrm{D}$ predominates). The data were then analyzed as non-constant ratio combinations, using the same software, where it is required to use linearized curves of the individual compounds with $r>0.95$ (Equation (2)), but allows the use of single-point data of the combinations, to determine the CI-value [37]. Those non-constant ratio combinations that were preliminarily synergistic were then validated by repeating the experiment as constant-ratio combinations, using 6-point curves, as previously described. All individual nutraceuticals and their combinations were tested on the same day.

\subsection{Cell Viability Assay}

Cell viability was evaluated by using the 3-(4,5-dimethylthiazol-2-yl)-5-(3-carboxymethoxyphenyl) -2-(4-sulfophenyl)-2H-tetrazolium (MTS) assay. Cells were seeded in tissue culture 96-well microplates (15,000 cells/well) in $100 \mu \mathrm{L}$ of medium supplemented with $1 \%$ Anti-Anti solution and incubated for $5 \mathrm{~h}$ at $37{ }^{\circ} \mathrm{C}$ and $5 \% \mathrm{CO}_{2}$. All individual nutraceuticals and their combinations were dissolved in DMSO and serially diluted in medium supplemented with $1 \%$ Anti-Anti solution. Each dilution was added to the cells, at appropriate doses $(\mu \mathrm{M})$, to obtain $\mathrm{CC}_{50}, \mathrm{CC}_{75}$, and $\mathrm{CC}_{90}$. For all cases, the final concentrations were $0.5 \%$ DMSO and $1 \%$ Anti-Anti. Cells with only medium and $0.5 \%$ DMSO were used as controls and considered $100 \%$ viable. A second control with only medium was used to verify that $0.5 \%$ DMSO was not cytotoxic to the cells, and indeed no cytotoxicity was observed (data not shown). Cells were incubated with each nutraceutical treatment for $24 \mathrm{~h}$ at the same culture conditions. After treatment, CellTiter $96^{\circledR}$ was added $(20 \mu \mathrm{L})$ and cells were incubated for $1 \mathrm{~h}$. Absorbance was read at $490 \mathrm{~nm}$ in a microplate reader (Synergy MX, BioTek Instruments, Winooski, VT, USA).

\subsection{Determination of Best Combination}

Cytotoxicity of all synergistic combinations was evaluated on Caco-2, HT-29, and FHC, using the same viability assay as described in Section 4.4. The combination that had more selectivity toward cancer cells was chosen as the best.

\subsection{Statistical Analysis}

For all cases, two independent experiments were done on different days, and each experiment had three replicates. Results were expressed as means \pm standard errors. Significant statistical differences were determined by One-Way Analysis of Variance (ANOVA), followed by Tukey's test $(p<0.05)$, using Minitab 18 software (State College, PA, USA).

\section{Conclusions}

In summary, different combinations of curcumin, sulforaphane, and dihydrocaffeic acid were evaluated over the viability of human colon cancer cells. SD(1:1) was synergistic against HT-29 cells at $90 \%$ cytotoxicity level, while $\mathrm{CD}(1: 4)$ was synergistic at all cytotoxic levels and $\mathrm{CD}(9: 2)$ was synergistic at $90 \%$ cytotoxicity level against Caco- 2 cells. The best combination was $\mathrm{SD}(1: 1)$, since it was both synergistic and significantly more cytotoxic for colon cancer cells than healthy colon cells. Mechanistic studies are needed to validate the proposed model of synergy between sulforaphane and dihydrocaffeic acid. It would be interesting to also assess the type of effect the combinations $\operatorname{SD}(1: 1), \operatorname{CD}(1: 4)$, and $\mathrm{CD}(9: 2)$ have on normal colon cells. The $\mathrm{SD}(1: 1)$ combination can serve as a basis for developing novel and highly effective food products for the prevention/co-treatment of colon cancer, using the proper ingredients and following an appropriate methodology.

Author Contributions: Conceptualization, J.S.-G., L.C.-Z. and D.A.J.-V.; methodology, J.S.-G., J.V.-C., D.A.J.-V., L.C.-Z. and S.O.S.-S.; formal analysis, J.S.-G.; investigation, J.S.-G.; resources, D.A.J.-V. and S.O.S.-S.; data curation, J.S.-G.; writing-Original draft preparation, J.S.-G.; writing-Review and editing, D.A.J.-V., L.C.-Z., S.O.S.-S. and J.V.-C.; supervision, D.A.J.-V.; project administration, J.S.-G. and D.A.J.-V.; funding acquisition, D.A.J.-V. and S.O.S.-S. All authors have read and agreed to the published version of the manuscript. 
Funding: Author J.S.-G. acknowledges CONACYT's scholarship \#291137. This work was supported by Bioprocess \& Synthetic Biology and NutriOmics research groups of Tecnologico de Monterrey.

Conflicts of Interest: The authors declare no conflict of interest. The funders had no role in the design of the study; in the collection, analyses, or interpretation of data; in the writing of the manuscript; or in the decision to publish the results.

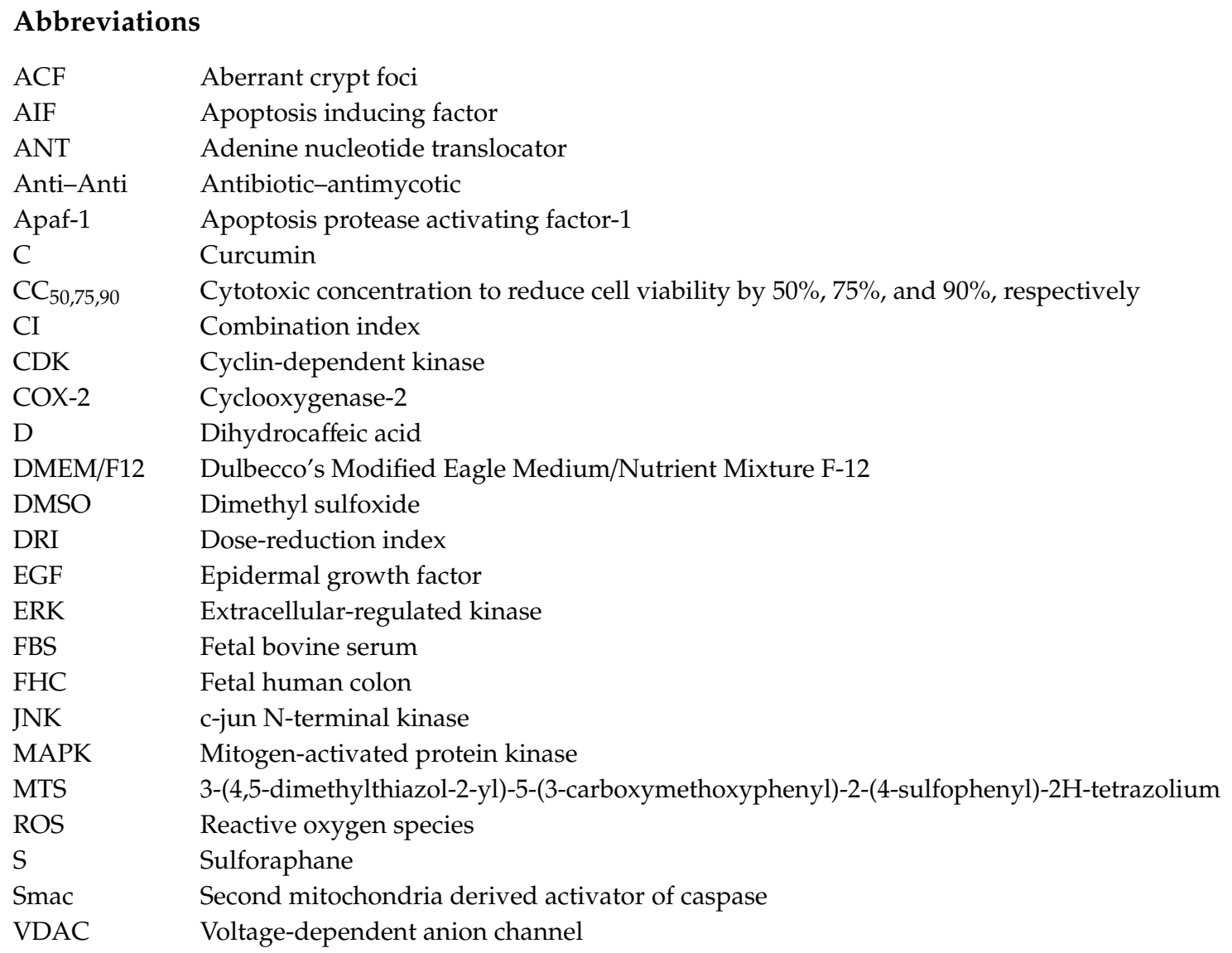

\section{References}

1. Cancer. Available online: https://www.who.int/news-room/fact-sheets/detail/cancer (accessed on 16 January 2020).

2. Santana-Gálvez, J.; Cisneros-Zevallos, L.; Jacobo-Velázquez, D.A. A practical guide for designing effective nutraceutical combinations in the form of foods, beverages, and dietary supplements against chronic degenerative diseases. Trends Food Sci. Technol. 2019, 88, 179-193. [CrossRef]

3. Montgomery, A.; Adeyeni, T.; San, K.K.; Heuertz, R.M.; Ezekiel, U.R. Curcumin sensitizes silymarin to exert synergistic anticancer activity in colon cancer cells. J. Cancer 2016, 7, 1250-1257. [CrossRef] [PubMed]

4. Shukla, Y.; George, J. Combinatorial strategies employing nutraceuticals for cancer development. Ann. N. Y. Acad. Sci. 2011, 1229, 162-175. [CrossRef] [PubMed]

5. Singh, M.; Shukla, Y. Combinatorial approaches utilizing nutraceuticals in cancer chemoprevention and therapy: A complementary shift with promising acuity. In Genomics, Proteomics and Metabolomics in Nutraceuticals and Functional Foods, 2nd ed.; Bagchi, D., Swaroop, A., Bagchi, M., Eds.; Wiley-Blackwell: Oxford, UK, 2015; pp. 185-216.

6. Jaiswal, A.S.; Marlow, B.P.; Gupta, N.; Narayan, S. $\beta$-Catenin-mediated transactivation and cell-cell adhesion pathways are important in curcumin (diferuylmethane)-induced growth arrest and apoptosis in colon cancer cells. Oncogene 2002, 21, 8414-8427. [CrossRef]

7. Su, C.C.; Chen, G.W.; Lin, J.G.; Wu, L.T.; Chung, J.G. Curcumin inhibits cell migration of human colon cancer Colo 205 cells through the inhibition of nuclear factor kappa B /p65 and down-regulates cyclooxygenase-2 and matrix metalloproteinase-2 expressions. Anticancer Res. 2006, 26, 1281-1288. 
8. Singh, N.; Shrivastav, A.; Sharma, R.K. Curcumin induces caspase and calpain-dependent apoptosis in HT29 human colon cancer cells. Mol. Med. Rep. 2009, 2, 627-631.

9. Villegas, I.; Sánchez-Fidalgo, S.; de la Lastra, C.A. Chemopreventive effect of dietary curcumin on inflammation-induced colorectal carcinogenesis in mice. Mol. Nutr. Food Res. 2011, 55, 259-267. [CrossRef]

10. Bounaama, A.; Djerdjouri, B.; Laroche-Clary, A.; Le Morvan, V.; Robert, J. Short curcumin treatment modulates oxidative stress, arginase activity, aberrant crypt foci, and TGF- $\beta 1$ and HES- 1 transcripts in 1,2-dimethylhydrazine-colon carcinogenesis in mice. Toxicology 2012, 302, 308-317. [CrossRef]

11. Carroll, R.E.; Benya, R.V.; Turgeon, D.K.; Vareed, S.; Neuman, M.; Rodriguez, L.; Kakarala, M.; Carpenter, P.M.; McLaren, C.; Meyskens, F.L., Jr.; et al. Phase IIa clinical trial of curcumin for the prevention of colorectal neoplasia. Cancer Prev. Res. 2011, 4, 354-364. [CrossRef]

12. Juge, N.; Mithen, R.F.; Traka, M. Molecular basis for chemoprevention by sulforaphane: A comprehensive review. Cell. Mol. Life Sci. 2007, 64, 1105-1127. [CrossRef]

13. Andělová, H.; Rudolf, E.; Červinka, M. In vitro antiproliferative effects of sulforaphane on human colon cancer cell line SW620. Acta Medica (Hradec Králové) 2007, 50, 171-176. [CrossRef]

14. Kim, D.H.; Sung, B.; Kang, Y.J.; Hwang, S.Y.; Kim, M.J.; Yoon, J.H.; Im, E.; Kim, N.D. Sulforaphane inhibits hypoxia-induced HIF-1 $\alpha$ and VEGF expression and migration of human colon cancer cells. Int. J. Oncol. 2015, 47, 2226-2232. [CrossRef]

15. Zeng, H.; Trujillo, O.N.; Moyer, M.P.; Botnen, J.H. Prolonged sulforaphane treatment activates survival signaling in nontumorigenic NCM460 colon cells but apoptotic signaling in tumorigenic HCT116 colon cells. Nutr. Cancer 2011, 63, 248-255. [CrossRef] [PubMed]

16. Chen, M.J.; Tang, W.Y.; Hsu, C.W.; Tsai, Y.T.; Wu, J.F.; Lin, C.W.; Cheng, Y.M.; Hsu, Y.C. Apoptosis induction in primary human colorectal cancer cell lines and retarded tumor growth in SCID mice by sulforaphane. Evid. Based Complement. Alternat. Med. 2012, 2012, 415231. [CrossRef] [PubMed]

17. Chung, F.L.; Conaway, C.C.; Rao, C.V.; Reddy, B.S. Chemoprevention of colonic aberrant crypt foci in Fischer rats by sulforaphane and phenethyl isothiocyanate. Carcinogenesis 2000, 21, 2287-2291. [CrossRef]

18. Egner, P.A.; Chen, J.G.; Wang, J.B.; Wu, Y.; Sun, Y.; Lu, J.H.; Zhu, J.; Zhang, Y.H.; Chen, Y.S.; Friesen, M.D.; et al. Bioavailability of sulforaphane from two broccoli sprout beverages: Results of a short-term, cross-over clinical trial in Qidong, China. Cancer Prev. Res. 2011, 4, 384-395. [CrossRef] [PubMed]

19. Vermeulen, M.; Klöpping-Ketelaars, I.W.; van den Berg, R.; Vaes, W.H. Bioavailability and kinetics of sulforaphane in humans after consumption of cooked versus raw broccoli. J. Agric. Food Chem. 2008, 56, 10505-10509. [CrossRef]

20. Santana-Gálvez, J.; Cisneros-Zevallos, L.; Jacobo-Velázquez, D.A. Chlorogenic acid: Recent advances on its dual role as a food additive and a nutraceutical against metabolic syndrome. Molecules 2017, 22, 358. [CrossRef]

21. Hou, N.; Liu, N.; Han, J.; Yan, Y.; Li, J. Chlorogenic acid induces reactive oxygen species generation and inhibits the viability of human colon cancer cells. Anti-Cancer Drugs 2017, 28, 59-65. [CrossRef]

22. Matsunaga, K.; Katayama, M.; Sakata, K.; Kuno, T.; Yoshida, K.; Yamada, Y.; Hirose, Y.; Yoshimi, N.; Mori, H. Inhibitory effects of chlorogenic acid on azoxymethane-induced colon carcinogenesis in male F344 rats. Asian Pac. J. Cancer Prev. 2002, 3, 163-166.

23. Olthof, M.R.; Hollman, P.C.; Katan, M.B. Chlorogenic acid and caffeic acid are absorbed in humans. J. Nutr. 2001, 131, 66-71. [CrossRef] [PubMed]

24. Ekbatan, S.S.; Sleno, L.; Sabally, K.; Khairallah, J.; Azadi, B.; Rodes, L.; Prakash, S.; Donnelly, D.J.; Kubow, S. Biotransformation of polyphenols in a dynamic multistage gastrointestinal model. Food Chem. 2016, 204, 453-462. [CrossRef]

25. Ludwig, I.A.; Paz de Peña, M.; Cid, C.; Crozier, A. Catabolism of coffee chlorogenic acids by human colonic microbiota. Biofactors 2013, 39, 623-632. [CrossRef] [PubMed]

26. Olthof, M.R.; Hollman, P.C.H.; Buijsman, M.N.C.P.; van Amelsvoort, J.M.M.; Katan, M.B. Chlorogenic acid, quercetin-3-rutinoside and black tea phenols are extensively metabolized in humans. J. Nutr. 2003, 133, 1806-1814. [CrossRef] [PubMed]

27. Santana-Gálvez, J.; Villela-Castrejón, J.; Serna-Saldívar, S.O.; Jacobo-Velázquez, D.A. Anticancer potential of dihydrocaffeic acid: A chlorogenic acid metabolite. CyTA J. Food 2020, 18, 245-248. [CrossRef] 
28. Pappa, G.; Strathmann, J.; Löwinger, M.; Bartsch, H.; Gerhäuser, C. Quantitative combination effects between sulforaphane and 3,3'-diindolylmethane on proliferation of human colon cancer cells in vitro. Carcinogenesis 2007, 28, 1471-1477. [CrossRef]

29. Nakamura, Y.; Yogosawa, S.; Izutani, Y.; Watanabe, H.; Otsuji, E.; Sakai, T. A combination of indole-3-carbinol and genistein synergistically induces apoptosis in human colon cancer HT-29 cells by inhibiting Akt phosphorylation and progression of autophagy. Mol. Cancer 2009, 8, 100. [CrossRef]

30. De Maria, S.; Scognamiglio, I.; Lombardi, A.; Amodio, N.; Caraglia, M.; Cartenì, M.; Ravagnan, G.; Stiuso, P. Polydatin, a natural precursor of resveratrol, induces cell cycle arrest and differentiation of human colorectal Caco-2 cell. J. Transl. Med. 2013, 11, 264. [CrossRef]

31. Xu, G.; Ren, G.; Xu, X.; Yuan, H.; Wang, Z.; Kang, L.; Yu, W.; Tian, K. Combination of curcumin and green tea catechins prevents dimethylhydrazine-induced colon carcinogenesis. Food Chem. Toxicol. 2010, 58, 390-395. [CrossRef]

32. Jin, G.; Yang, Y.; Liu, K.; Zhao, J.; Chen, X.; Liu, H.; Bai, R.; Li, X.; Jiang, Y.; Zhang, X.; et al. Combination curcumin and (-)-epigallocatechin-3-gallate inhibits colorectal carcinoma microenvironment-induced angiogenesis by JAK/STAT3/IL-8 pathway. Oncogenesis 2017, 6, e384. [CrossRef]

33. Majumdar, A.P.N.; Banerjee, S.; Nautiyal, J.; Patel, B.B.; Patel, V.; Du, J.; Yu, Y.; Elliot, A.A.; Levi, E.; Sarkar, F.H. Curcumin synergizes with resveratrol to inhibit colon cancer. Nutr. Cancer 2009, 61, 544-553. [CrossRef] [PubMed]

34. Shen, G.; Khor, T.O.; Hu, R.; Yu, S.; Nair, S.; Ho, C.T.; Reddy, B.S.; Huang, M.T.; Newmark, H.L.; Kong, A.N.T. Chemoprevention of familial adenomatous polyposis by natural dietary compounds sulforaphane and dibenzoylmethane alone and in combination in Apc ${ }^{\mathrm{Min} /+}$ mouse. Cancer Res. 2007, 67, 9937-9944. [CrossRef] [PubMed]

35. Bhatnagar, N.; Li, X.; Chen, Y.; Zhou, X.; Garrett, S.H.; Guo, B. 3,3'-Diindolylmethane enhances the efficacy of butyrate in colon cancer prevention through down-regulation of survivin. Cancer Prev. Res. 2009, 2, 581-589. [CrossRef] [PubMed]

36. Cruz-Correa, M.; Shoskes, D.A.; Sanchez, P.; Zhao, R.; Hylind, L.M.; Wexner, S.D.; Giardiello, F.M. Combination treatment with curcumin and quercetin of adenomas in familial adenomatous polyposis. Clin. Gastroenterol. Hepatol. 2006, 4, 1035-1038. [CrossRef]

37. Chou, T.C. Theoretical basis, experimental design, and computerized simulation of synergism and antagonism in drug combination studies. Pharmacol. Rev. 2006, 58, 621-681. [CrossRef]

38. Doldán-Martelli, V.; Míguez, D.G. Synergistic interaction between selective drugs in cell populations models. PLOS ONE 2015, 10, e0117558. [CrossRef]

39. Shen, G.; Xu, C.; Chen, C.; Hebbar, V.; Kong, A.N.T. p53-independent $\mathrm{G}_{1}$ cell cycle arrest of human colon carcinoma cells HT-29 by sulforaphane is associated with induction of $\mathrm{p}_{21}{ }^{\mathrm{CIP} 1}$ and inhibition of expression of cyclin D1. Cancer Chemother. Pharmacol. 2006, 57, 317-327. [CrossRef]

40. Gamet-Payrastre, L.; Li, P.; Lumeau, S.; Cassar, G.; Dupont, M.A.; Chevolleau, S.; Gasc, N.; Tulliez, J.; Tercé, F. Sulforaphane, a naturally occurring isothiocyanate, induces cell cycle arrest and apoptosis in HT29 human colon cancer cells. Cancer Res. 2000, 60, 1426-1433.

41. Parnaud, G.; Li, P.; Cassar, G.; Rouimi, P.; Tulliez, J.; Combaret, L.; Gamet-Payrastre, L. Mechanism of sulforaphane-induced cell cycle arrest and apoptosis in human colon cancer cells. Nutr. Cancer 2004, 48, 198-206. [CrossRef]

42. Dabrowska, C.; Li, M.; Fan, Y. Apoptotic caspases in promoting cancer: Implications from their roles in development and tissue homeostasis. In Apoptosis in Cancer Pathogenesis and Anti-cancer Therapy: New Perspectives and Opportunities, 1st ed.; Gregory, C.D., Ed.; Springer: Berlin/Heidelberg, Germany, 2016; pp. 89-112.

43. Hu, Q.; Wu, D.; Chen, W.; Yan, Z.; Shi, Y. Proteolytic processing of the caspase-9 zymogen is required for apoptosome-mediated activation of caspase-9. J. Biol. Chem. 2013, 288, 15142-15147. [CrossRef]

44. Rashmi, R.; Kumar, S.; Karunagaran, D. Human colon cancer cells lacking Bax resist curcumin-induced apoptosis and Bax requirement is dispensable with ectopic expression of Smac or downregulation of Bcl-XL. Carcinogenesis 2005, 26, 713-723. [CrossRef] [PubMed]

45. Debatin, K.M.; Poncet, D.; Kroemer, G. Chemotherapy: Targeting the mitochondrial cell death pathway. Oncogene 2002, 21, 8786-8803. [CrossRef] [PubMed]

46. Jaganathan, S.K. Growth inhibition by caffeic acid, one of the phenolic constituents of honey, in HCT 15 colon cancer cells. Sci. World J. 2012, 2012, 372345. [CrossRef] [PubMed] 
47. Papi, A.; Farabegoli, F.; Iori, R.; Orlandi, M.; De Nicola, G.R.; Bagatta, M.; Angelino, D.; Gennari, L.; Ninfali, P. Vitexin-2-O-xyloside, raphasatin and (-)-epigallocatechin-3-gallate synergistically affect cell growth and apoptosis of colon cancer cells. Food Chem. 2013, 138, 1521-1530. [CrossRef] [PubMed]

48. Wang, S.; Sarriá, B.; Mateos, R.; Goya, L.; Bravo-Clemente, L. TNF- $\alpha$-induced oxidative stress and endothelial dysfunction in EA.hy926 cells is prevented by mate and green coffee extracts, 5-caffeoylquinic acid and its microbial metabolite, dihydrocaffeic acid. Int. J. Food Sci. Nutr. 2019, 70, 267-284. [CrossRef]

49. Collett, G.P.; Campbell, F.C. Curcumin induces c-jun N-terminal kinase-dependent apoptosis in HCT116 human colon cancer cells. Carcinogenesis 2004, 25, 2183-2189. [CrossRef]

50. Goel, A.; Boland, C.R.; Chauhan, D.P. Specific inhibition of cyclooxygenase-2 (COX-2) expression by dietary curcumin in HT-29 human colon cancer cells. Cancer Lett. 2001, 172, 111-118. [CrossRef]

51. Wang, M.; Chen, S.; Wang, S.; Sun, D.; Chen, J.; Li, Y.; Han, W.; Yang, X.; Gao, H.Q. Effects of phytochemicals sulforaphane on uridine diphosphate-glucuronosyltransferase expression as well as cell-cycle arrest and apoptosis in human colon cancer Caco-2 cells. Chin. J. Physiol. 2012, 55, 134-144.

52. Seeram, N.P.; Adams, L.S.; Henning, S.M.; Niu, Y.; Zhang, Y.; Nair, M.G.; Heber, D. In vitro antiproliferative, apoptotic and antioxidant activities of punicalagin, ellagic acid and a total pomegranate tannin extract are enhanced in combination with other polyphenols as found in pomegranate juice. J. Nutr. Biochem. 2005, 16, 360-367. [CrossRef]

(C) 2020 by the authors. Licensee MDPI, Basel, Switzerland. This article is an open access article distributed under the terms and conditions of the Creative Commons Attribution (CC BY) license (http://creativecommons.org/licenses/by/4.0/). 